\title{
SPLETNO PODPRTO UČENJE IN POUČEVANJE NEMŠČINE NA SEKUNDARNI RAVNI
}

\section{UVOD}

Današnja mladina je obdana $\mathrm{z}$ informacijsko in komunikacijsko tehnologijo (IKT), kot so npr. mobilni telefoni, računalniki, MP3 predvajalniki in splet. Uporabljajo jo predvsem v prostem času, za zabavo in komuniciranje. Sodobna IKT skriva v sebi velike potenciale tudi za uporabo v šoli, za učenje. Toda, ali znamo tehnologijo, ki jo mladi obvladajo, uporabiti tudi v učnem procesu? Če mlade vzamemo resno, potem menim, da je naloga učitelja, da se sooči tudi z IKT in ji poišče ustrezno mesto $v$ šoli. Politika EU v obliki sofinanciranja raznih projektov podpira integracijo IKT v pouk. Izsledki različnih raziskav (npr. Gerlič 2009, Mladina 2010) kažejo, da je opremljenost šol ter dostop do IKT in spleta $\mathrm{v}$ Sloveniji dobra in ponekod celo nad povprečjem EU. Poleg tega potekajo tudi sistematična izobraževanja učiteljev, predvsem v okviru projekta E-šolstvo. Lahko bi sklenili, da so predpogoji za uvajanje IKT v učni proces v slovenske šole relativno dobri. Tako je $\mathrm{v}$ strokovni literaturi in na konferencah vsako leto predstavljenih veliko primerov dobre prakse. Vprašanje pa je, če in v kolikšni meri ti primeri dobre prakse dejansko spreminjajo paradigmo učenja in poučevanja $\mathrm{v}$ širšem kontekstu.

$\mathrm{V}$ prispevku bomo orisali različne oblike integracije IKT $\mathrm{v}$ pouk nemščine. Natančneje pa se bomo posvetili le eni obliki, to je spletno podprtemu pouku. Kontekst analize predstavlja učenje nemščine in posredno ostalih tujih jezikov na sekundarni ravni, torej na šolskem polju, kjer učni proces poteka na tradicionalni način, $\mathrm{v}$ živo ob prisotnosti učitelja in učencev na istem mestu in ob istem času. Predstavili in analizirali bomo model za uvajanje spletno podprtega učenja ter kot enega od ključnih dejavnikov izpostavili načelo postopnosti.

\section{INTEGRACIJA IKT V UČNI PROCES}

Klasično pojmovanje pouka se nanaša na izvajanje učnega procesa v živo, ob istem času na istem mestu in pod vodstvom učitelja. S popularizacijo spleta na šolskem polju pa se klasična oblika pouka spreminja. Faze učenja v živo se lahko dopolnijo s fazami učenja na daljavo, s čemer pouk ob uporabi IKT pridobiva novo dimenzijo. Obseg faz učenja na daljavo je različen, razpon lahko sega od občasnega samostojnega dela na daljavo do daljših časovnih obdobij, v katerih se učenci pod 
vodstvom učitelja samostojno učijo. Schulmeister (2006: 192) loči glede na obseg integracije e-učenja $\mathrm{v}$ pouk $\mathrm{v}$ živo štiri oblike:

pouk v živo,

spletno podprti pouk,

kombinirano učenje,

virtualni pouk.

Pouk $\mathrm{v}$ živo poteka klasično, ob istem času na istem mestu ter ob prisotnosti učitelja. IKT se pri pouku ne uporablja, doma pa učenci npr. le občasno uporabijo splet za iskanje virov.

Spletno podprti pouk poteka klasično, le da učitelj in/ali učenci občasno pri pouku uporabljajo npr. spletno učno okolje za dostop do dodatnih gradiv in informacij ter za izvedbo spletno podprtih učnih dejavnosti.

Kombinirano učenje (ang. blended learning) se izvaja v okviru vodenega učnega procesa, kjer pomemben delež zajema klasični pouk v živo. Nekatere dejavnosti pa potekajo asinhrono, na daljavo in ob podpori IKT, za kar je značilna tako prostorska kot tudi časovna ločenost subjektov učnega procesa.

Pri virtualnem pouku pouk po uvodni predstavitvi v živo ali na daljavo poteka izključno na daljavo. Učni proces vodi učitelj, poteka pa tako sinhrono kot tudi asinhrono. Takšna oblika za našo ciljno skupino ni primerna, saj je uporabna predvsem za krajša izobraževanja izkušenih uporabnikov e-učenja.

Pri zgoraj opisanih oblikah variira delež uporabe IKT za izvedbo učnega procesa od nič ali malo do poteka pouka izključno s podporo IKT. V prispevku se bomo osredotočili na spletno podprt pouk, ki je za dani kontekst najbolj realna oblika.

\section{SPLETNO PODPRTO UČENJE}

Kot predhodnika spletno podprtega učenja tujih jezikov lahko razumemo računalniško podprto učenje jezikov. Termin z najdaljšo tradicijo je Computer Assisted Language Learning (CALL), kar pomeni računalniško podprto učenje jezikov. $\mathrm{Z}$ razvojem interneta in svetovnega spleta $\mathrm{v}$ začetku 90 -tih let prejšnjega so se uveljavili še drugi termini, npr. spletno podprto učenje, e-učenje, e-izobraževanje, za okolja, v katerih takšno učenje poteka pa npr. spletno učno okolje, e-učno okolje, spletna učilnica in e-učilnica. V Sloveniji je terminologija za to področje še precej neenotna, saj je še v procesu nastajanja in izoblikovanja. Vanda Rebolj je v monografiji E-izobraževanje skozi očala pedagogike in didaktike (2008) razložila uporabljene besede in besedne zveze s področja e-izobraževanja, pri čemer se je opirala na različne slovenske vire. Seznam obsega skoraj 300 gesel, kar je odlično izhodišče za razpravo o terminologiji. E-izobraževanje opredeli kot »ciljno naravnan, strukturiran in namenski proces, $v$ katerem $s$ pomočjo učenja ob podpori informacijskokomunikacijske tehnologije pridobivamo nova znanja in pozitivno spreminjamo osebnost«, e-učenje pa kot »namerno ali naključno pridobivanje novega znanja, ki poteka ob podpori informacijsko komunikacijske tehnologije« (Rebolj 2008: 195-196). Sulčič (2008: 22) loči dva vidika pojma e-izobraževanje, procesnega in sistemskega. Sistemski se nanaša na z IKT podprte vsebine, procesni pa na način 
izvajanja izobraževalnega procesa. Oba vidika sta neločljivo povezana, saj je ustrezna IKT predpogoj za izvedbo e-izobraževanja, ki pa mora biti zasnovano tako, da upošteva načela sodobne didaktike e-izobraževanja.

$\mathrm{V}$ prispevku bomo uporabili sintagmo spletno podprto učenje, ki v našem kontekstu označuje pridobivanje znanja in usvajanje tujega jezika pod vodstvom učitelja ter ob podpori IKT.

\section{SPLETNO UČNO OKOLJE}

Za okolje, v katerem to učenje poteka in ki je podprto z učno platformo, Rebolj (2008) uporablja termine učno okolje, spletno učno okolje, e-učno okolje, učno e-okolje ali samo e-okolje. V glosarju je opredeljeno zgolj učno okolje in sicer kot »skupnost učne vsebine, pogojev za učenje ter tehničnih, pedagoških in psiholoških dejavnikov« (Rebolj 2008: 211). Sulčič (2008: 92) spletno učno okolje razume kot sopomenko za e-učilnico.

Uporabo terminov smo preverili tudi na spletnih straneh ustanov, kjer izobražujejo bodoče učitelje tujih jezikov. Filozofska fakulteta Univerze v Ljubljani (FF UL) ima Portal FF za spletno podprto učenje (http://e-ucenje.ff.uni-lj.si/), kjer najdemo termine spletno okolje Moodle, spletno podprto učenje, e-učenje in e-izobraževanje, Pedagoška fakulteta Univerze v Ljubljani (PeF UL) ima Spletno učilnico PeF (http://ucilnica.pef.uni-lj.si/), Univerza v Mariboru (UM) nudi za vse fakultete enoten Portal e-študij (https://estudij.uni-mb.si/), kjer najdemo termine poučevalno/učno e-okolje, e-izobraževanje, e-študij in e-učenje, Pedagoška fakulteta Univerze na Primorskem (PeF UP) pa ima Portal e-okolje (https://e.pef.upr.si/), kjer se uporabljata termina učno okolje in e-učno okolje. $\mathrm{V}$ vseh navedenih ustanovah poteka e-izobraževanje v enakem sistemu, to je Moodle.

Pregledali smo tudi spletne strani nekaterih gimnazij, kjer smo brez izjeme našli sistem Moodle, ki ga največkrat označujejo kot e-učilnico, redkeje kot spletno učilnico.

Če povzamemo, je na sekundarni ravni najbolj pogost izraz e- ali spletna učilnica, na terciarni pa $e$ - ali spletno (učno) okolje. Ali se za različnim poimenovanjem skriva tudi drugačen pristop? Zgolj predpostavljamo lahko, da se z uporabo termina učilnica poudari po predmetih ločeno in ožje usmerjeno učenje posameznih predmetnih vsebin, za terminom okolje pa bi se lahko razumelo širše in kompleksnejše zastavljen koncept spletno podprtega študija.

$\mathrm{V}$ našem prispevku razumemo širši pomen pojma spletno učno okolje kot vse spletne strani, ki jih učitelj lahko vključi v učni proces z namenom doseganja zastavljenih učnih ciljev. Širše gledano predstavlja celotni svetovni splet potencialno spletno učno okolje, dejansko pa voden proces učenja z jasno zastavljenimi učnimi cilji zahteva primerno platformo, v okviru katere so smiselno organizirane učne vsebine. V ožjem kontekstu spletno učno okolje (SUO) predstavlja e-učilnica, ki služi za sistematično in strukturirano vodenje učnega procesa v spletnem okolju.

SUO je za učenje tujega jezika zelo primerna tehnologija, ker omogoča prenos informacij, ocenjevanje učnega procesa, predvsem pa komunikacijo in interakcijo ter soustvarjanje vsebine (prim. Setzinger 2010). Orodja, kot so forum, wiki in 
klepetalnica omogočajo razvijanje pisne zmožnosti in zmožnosti medkulturne komunikacije.

Kot smo omenili že zgoraj, se širši pomen pojma spletno učno okolje nanaša na spletne strani, ki jih učitelj lahko vključi v učni proces. Glede na funkcijo ločimo med spletnimi okolji, ki so primarno namenjena splošni uporabi in takimi, ki so razvita v izobraževalne namene. $V$ nadaljevanju se bomo omejili na SUO, ki so ciljno namenjena izobraževanju. Takšna SUO praviloma predstavljajo z geslom zaščiten prostor na spletu, kar je pomemben dejavnik še posebej v primeru, ko so dejavnosti v SUO zasnovane tako, da v njih poteka osebna komunikacija med udeleženci učnega procesa.

Za učinkovito vodenje spletno podprtega pouka je pomemben dejavnik tudi usposobljen učitelj.

\section{USPOSOBLJENOST UČITELJEV ZA DELO S SPLETNIM UČNIM OKOLJEM}

Za pouk nemščine je na voljo veliko učbenikov in delovnih zvezkov. Bogato zakladnico dodatnih gradiv pa predstavlja tudi splet, kjer učitelji poiščejo informacije in gradiva ter jih prilagodijo za svoj pouk. Iskanje informacij in že izdelanih gradiv za pouk na spletu sta tudi najbolj pogosta načina rabe spleta med učitelji nemščine (Podgoršek 2011: 65). Vendar pa splet in spletne storitve omogočajo mnogo več možnosti, za kar pa učitelji poleg predmetno specifičnih znanj potrebujejo še dodatna znanja in zmožnosti. Katere so te zmožnosti in znanja? V Izhodiščih standarda e-kompetentni učitelj, ravnatelj in računalnikar (Kreuh/Brečko 2011: 18-19) je opredeljenih naslednjih šest zmožnosti:

1. Poznavanje in zmožnost kritične uporabe IKT;

2. Zmožnost komunikacije in sodelovalnega dela na daljavo:

3. Zmožnost iskanja, zbiranja, obdelovanja, vrednotenja (kritične presoje podatkov), informacij in konceptov;

4. Varna raba in upoštevanje pravnih in etičnih načel uporabe ter objave informacij;

5. Izdelava, ustvarjanje, posodabljanje, objava izdelkov (gradiv);

6. Zmožnost načrtovanja, izvedbe, evalvacije pouka učenja in poučevanja $z$ uporabo IKT.

Opisana paleta znanj in zmožnosti je izjemno široka, saj poleg poznavanja ustrezne strojne in programske opreme ter njenih didaktični potencialov obsega tudi avtorsko zmožnost učiteljev ter poznavanje pravnih in etičnih načel rabe IKT pri pouku. Tako opredeljene zmožnosti predstavljajo splošen standard, nas pa zanima, katere specifične zmožnosti in znanja naj bi obvladal učitelj nemščine. V okviru E-šolstva nastaja predlog standarda e-kompetentni učitelj tujih jezikov (vključeni so tudi učitelji nemščine). Postopek nastajanja predloga je bil predstavljen na konferenci SIRIKT (Kač/Košir 2011). Okvir oblikovanja standarda je predstavljal zgoraj omenjen koncept šestih e-kompetenc, poleg tega pa tudi nabor zmožnosti, ki naj bi jih učitelji tujih jezikov razvili v okviru seminarjev za učitelje tujih jezikov (Kač/Košir 2011: 291). Predlog standarda obsega tri zahtevnostne 
ravni, ki se nadgrajujejo. Usvojena prva raven je torej podlaga za drugo, druga pa za tretjo raven. Na prvi ravni naj bi učitelj tujega jezika obvladal začetno uporabo IKT, Moodle in spletnik. Druga raven obsega pouk v spletni učilnici in mrežni projekt, tretja pa izdelavo e-gradiv, izbrane storitve spleta 2.0 in jezikovni e-portfolio. Ravni so natančno opredeljene $z$ navedbo zmožnosti, seznam obsega 40 različnih zmožnosti in znanj. Ker je seznam zelo obsežen, se postavlja vprašanje, v kolikšni meri so navedene zmožnosti v takšnem obsegu relevantne za šolsko prakso. Predlog standarda je nastal na podlagi koncepta šestih e-kompetenc in seminarjev za učitelje, kot smo navedli že zgoraj. Menimo, da bi veljalo seznam preveriti tudi v praksi, torej pri učiteljih tujih jezikov in k dvema zgoraj omenjenima okviroma oblikovanja standarda dodati še perspektivo učitelja praktika.

$\mathrm{V}$ nadaljevanju se bomo posvetili problematiki izbire primernega medija oziroma IKT za učenje in poučevanje nemščine.

\section{DEJAVNIKI, KI VPLIVAJO NA IZBIRO PRIMERNEGA MEDIJA ZA POUK TUJEGA JEZIKA}

Od česa je torej odvisno, ali bo učitelj uporabil ustaljene in preverjene metode dela ali pa novejše, ki so povezano z uporabo sodobne IKT? Učitelj se za izbor ustreznega medija lahko odloči na podlagi različnih meril in dejavnikov. Navdušenje učencev nad IKT in njihova motivacija za delo z njimi sta dva pomembna dejavnika (Podgoršek 2011: 63-64), vendar pa ne zadoščata, saj prvo navdušenje nad tehnologijo lahko hitro mine. Pri pouku tujih jezikov je pomemben dejavnik tudi dejstvo, da IKT omogoča hiter dostop do avtentičnih in aktualnih besedil ter zvočnih in video posnetkov. Kateri pa so osnovni dejavniki, ki vplivajo na izbiro ustreznega medija, v našem primeru IKT pri pouku? Kalin (2004: 213-214) navaja naslednje:

(1) namen in cilj pouka,

(2) učna vsebina,

(3) učne metode, oblike in pristopi,

(4) značilnosti socialnega okolja,

(5) značilnosti učencev in učitelja ter

(6) značilnosti medija.

$\mathrm{V}$ nadaljevanju bomo ob opisu posameznih dejavnikov navedli nekaj argumentov za in proti izbiri metode spletno podprtega učenja nemščine na sekundarni ravni.

(1) Cilj pouka nemščine v gimnaziji je v učnem načrtu (2008: 10) opredeljen kot doseganje sporazumevalne zmožnosti. Razdeljen je na razvijanje zmožnosti sprejemanja besedil (poslušanje in branje - receptivne zmožnosti), zmožnosti tvorjenja besedil (govorjenje in pisanje - produktivne zmožnosti), zmožnosti sporazumevanja (govorno in pisno sporazumevanje - interakcija), zmožnosti posredovanja oziroma povzemanja vsebine govorjenih in pisnih besedil (govorno in pisno jezikovno posredovanje - mediacija) in medkulturne zmožnosti. Naštete zmožnosti lahko v veliki meri razvijamo tudi v spletenem učnem okolju, ki omogoča različne načine komunikacije in sodelovalnega učenja. Za avtentično komu- 
nikacijo v tujem jeziku, ki je pomemben cilj tujejezikovnega pouka, lahko uporabimo sinhrone načine komuniciranja (spletno klepetalnico, ICQ in asinhrone (e-pošta, forum, wiki, blog). Na eni strani zasnova, priprava in izvedba tovrstnih nalog zahteva od učitelja veliko časa in znanja, zato se nam postavi vprašanje o razmerju med vloženim delom in časom ter dodano vrednostjo za učence, po drugi strani pa naloge, izdelane za izbrano ciljno skupino, lahko omogočajo visoko stopnjo individualizacije in diferenciacije.

(2) Učna vsebina je pri pouku tujih jezikov določena $z$ učnim načrtom, operacionalizirana pa v veliki meri z izbiro učbenika. SUO omogoča učitelju, da v pouk vključi aktualne in avtentične večpredstavnostne vsebine. Predvsem za fazo ponavljanja in utrjevanja znanja slovničnih struktur, besedišča in posameznih jezikovnih zmožnosti so primerne interaktivne vaje s takojšnjo povratno informacijo.

(3) SUO omogoča raznolike učne metode in učne oblike. SUO lahko služi kot zbirka gradiv in interaktivnih nalog, kot orodje za sinhrono in asinhrono komunikacijo ter kot platforma za izvedbo spletne učne poti in projektnega dela. Socialne učne oblike so podobne kot pri tradicionalnem pouku, od individualnega učenja, do dela $v$ paru in skupinskega dela. Težišče aktivnosti učitelja je na načrtovanju, pripravi in evalvaciji pouka, pri sami izvedbi pa je v ospredju učenec, par ali skupina. SUO so primerna za izvedbo sodelovanja dveh partnerskih razredov, pri čemer je za uspešnost sodelovanja pomembno natančno načrtovanje dela in usklajeno delovanje učiteljev obeh razredov.

(4) SUO je prav tako kot šola socialen prostor, v katerem veljajo določena pravila. Naloga učitelja je, da skupaj z učenci zgradi takšno virtualno skupnost, v kateri bodo vsi dobili priložnost za komuniciranje in razvijanje zmožnosti sodelovalnega učenja in doseganja zastavljenih ciljev. Za učence, ki pri pouku v živo redko prispevajo svoje zamisli ali postavljajo vprašanja, predstavlja SUO možnost, da se izrazijo na njim lasten način in v tempu, ki jim ustreza, kar velja predvsem za asinhrono komuniciranje. Učitelj mora $\mathrm{v}$ učni proces $\mathrm{v}$ SUO vgraditi krajše dejavnosti, ki imajo namen, da učencem korak za korakom omogočajo pozitivne izkušnje pri učenju. Pri projektnem delu in sodelovanju partnerskih razredov iz različnih regij in držav pa učenci v SUO poleg sporazumevalne razvijajo tudi medkulturno zmožnost.

(5) Pri pouku mora učitelj upoštevati razvojno stopnjo učencev, njihovo predznanje jezika in znanje za učenje s podporo IKT. Uspešnost uvajanja IKT v učni proces je v veliki meri odvisna od usposobljenosti učitelja ter naklonjenosti spremembam $v$ učnem procesu vseh posredno in neposredno udeleženih, učenca, učitelja, ravnatelja ter odločevalcev na lokalni in nacionalni ravni, kar potrjujejo tudi izsledki različnih domačih in tujih raziskav, ki se ukvarjajo z IKT pri pouku (npr. Gerlič 2005, Empirica 2006, Sulčič 2008, Peklaj et al. 2009, Kač 2009, Podgoršek 2011). Menimo, da učiteljeva naloga ni popolnoma obvladati najnovejšo tehnologijo, temveč poznati osnovne funkcije in principe delovanja IKT za izobraževalne namene. Čeprav je mladina dandanes vešča dela $\mathrm{z}$ računalnikom in spletom pa bi bilo zmotno pričakovati, da vsi poznajo in razumejo vrednost IKT za učenje. $V$ primeru, ko učenci IKT obvladajo bolje kot učitelj, lahko v tem vidimo pomanjkljivost ali prednost. Prednosti zazna predvsem suvereni učitelj, ki učence povabi, da mu pomagajo in jih $\mathrm{s}$ tem postavi v vlogo učitelja, sebe pa v vlogo učenca. Ob 
tem oba pridobita novo znanje. Po drugi strani pa se učitelji, ki IKT ne obvladajo ali se ne želijo ukvarjati z njo, sploh ne podajo na ta nov teren, saj lastno neznanje doživljajo kot problem in ne kot izziv, s katerem se bo potrebno nekega dne soočiti.

(6) Značilnosti SUO je potrebno razumeti iz historične perspektive razvoja medija in metod poučevanja. Metode poučevanja tujih jezikov se ves čas spreminjajo, na kar vplivajo izsledki različnih teorij učenja kot tudi družbeni dejavniki in tehnološki razvoj. Prav tako je razvoju podvrženo računalniško podprto učenje jezikov (ang. Computer Assisted Language Learning) iz katerega se je razvilo e-učenje. Razvoj je potekal po fazah, ki jih Warschauer (1996) opredeli kot behavioristično, komunikacijsko in integrativno. Za behavioristično fazo v 60-ih in 70ih letih prejšnjega stoletja so značilne vaje mehaničnega urjenja in ponavljanja (dril). Računalniški programi so nudili predvsem slovnične vaje, vaje za besedišče in prevajanje. $\mathrm{V}$ komunikacijski fazi iz konca 70-tih in začetka 80-tih let je razvoj komunikacijskega pristopa $\mathrm{k}$ poučevanju tujih jezikov narekoval tudi spremembo in nadgradnjo obstoječih vaj z bolj komunikativnimi. Za to fazo so značilne vaje kot npr. rekonstrukcija besedila, urjenje posameznih jezikovnih zmožnosti, jezikovne igre in konkordance. Sledila je integrativna faza, ki sta jo omogočili dve pomembni tehnološki novosti, multimedijski računalnik in internet. Zanjo so značilni programi za učenje tujih jezikov, ki temeljijo na multimedijskih zmožnostih računalnika (besedilo, slika, grafika, zvok, animacije, video, hipermedija). Internet pa omogoča neposreden dostop do avtentičnih besedil in komunikacijo z govorci ciljnega jezika za relativno malo stroškov. Obe novi dimenziji, dostop do avtentičnih informacij in komunikacija s pomočjo interneta, omogočata široko paleto možnosti uporabe računalnika pri pouku tujih jezikov.

\section{UVAJANJE SPLETNO PODPRTEGA UČENJA V UČNI PROCES}

V strokovni literaturi najdemo različne modele e-izobraževanja. Za naš kontekst so relevantni mikro modeli, ki se nanašajo na učni proces in jih je možno aplicirati na poučevanje na sekundarni ravni. Glede na naravo predmeta, ki se poučuje, in na zastavljene učne cilje, je za pouk tujega jezika, pri katerem je osrednji cilj razvijanje sporazumevalne zmožnosti, primeren model razvijanja sodelovalnega učenja v SUO, ki ga je zasnovala Gilly Salmon. V našem primeru v SUO ne sodeluje virtualna, ampak realna razredna skupnost ali projektna skupina, ki redno sodeluje tudi v živo.

\subsection{Petstopenjski model uvajanja učenja v spletnem okolju}

Poučevanje v SUO se razlikuje od tradicionalnega poučevanja v živo, čeprav zanj veljajo podobne zakonitosti. Za učitelja predstavlja vodenje učnega procesa v SUO zahtevno nalogo, ker za razliko od tradicionalnega pouka praviloma ne more takoj opaziti odziva in preveriti razumevanja učencev, ko delo poteka na daljavo. Zato je še toliko bolj pomembno, da se dela loti načrtno in upošteva splošna didaktična načela. Uvajanje v sodelovalno učenje v SUO naj poteka postopno, 
učence je smiselno voditi npr. od nalog zaprtega tipa do bolj odprtih in problemsko naravnanih. Fazi izvedbe učnih dejavnosti sledi faza evalvacije uporabljenih metod in doseženih ciljev, na podlagi katere učitelj načrtuje nadaljnje delo.

Korake uvajanja spletno podprtega učenja je zelo dobro opisala in operacionalizirala Gilly Salmon v petstopenjskem modelu (Salmon 2004). V primeru uvajanja spletno podprtega učenja je implementacija omenjenega modela pomembna za uspešen potek učenja. Komunikacija temelji na pisni interakciji, ki pa je v primerjavi z interakcijo $\mathrm{v}$ živo okrnjena, saj se sogovornika ne vidita. Za uspešno učenje je torej pomembno obojestransko zaupanje in upoštevanje pravil komuniciranja. Pri kombiniranem pouku, torej takrat, ko pouk poteka v živo in tudi na daljavo, lahko učitelj nekatere faze petstopenjskega modela izvede tudi pri kontaktnih urah. Pomembno je, da se prepriča, ali so vsi učenci usvojili ustrezno fazo, in se šele potem loti naslednje.

Katere so torej stopnje, ki vodijo do samostojnega spletno podprtega učenja v SUO? Salmon (2004) navaja naslednjih pet: dostop in motivacija, online socializacija, izmenjava informacij, konstrukcija znanja in razvoj (Slika 1).

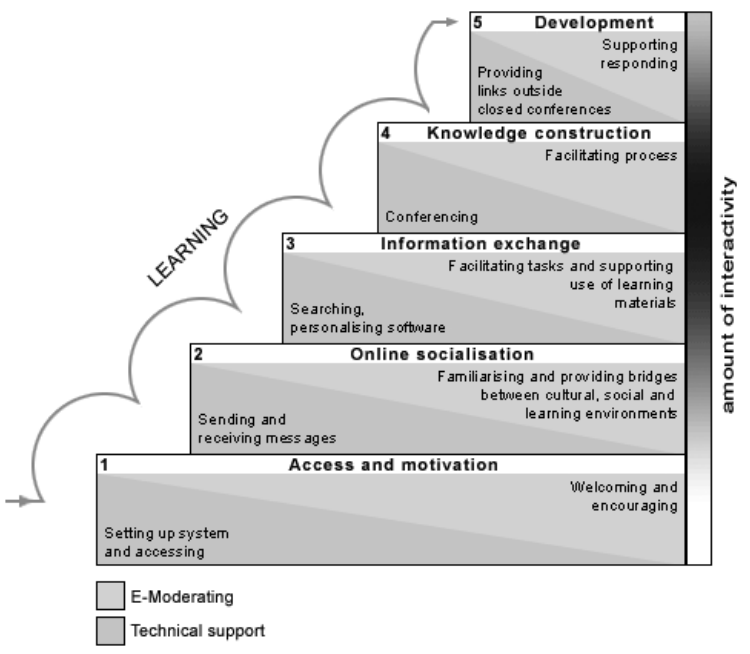

Slika 1: Petstopenjski model uvajanja spletno podprtega učenja (Salmon 2004)

Na prvi stopnji učitelj uvede učence v delo s SUO ter jih motivira za učenje. Motiviranje učencev pa je mogoče le, če učitelj učence dobro pozna. V ta namen učitelj oblikuje kratke dejavnosti, ki jih Salmon imenuje e-dejavnosti (ang. e-tivities). Ta del lahko učitelj skrajša ali preskoči, če učence poučuje v živo in je pri pouku že uporabil druge metode, da je ugotovil, kaj učence zanima, kakšne so njihove vrednote in učni stili. Za to fazo uvajanja spletno podprtega učenja je značilna enosmerna komunikacija od učitelja do učenca, kot je npr. komuniciranje v smislu sporočanja informacij učencem ali prenos informacij, kot so npr. učni listi, zvočni ali videoposnetki. Ko učitelj ugotovi, da so vsi učenci vpisani $\mathrm{v}$ spletno učno okolje in da obvladajo osnovne funkcije, je prva stopnja zaključena. 
Druga stopnja se nanaša na socializacijo v SUO. Socializacija vključuje interakcijo $z$ učiteljem in učenci, poznavanje in upoštevanje pravil obnašanja ter znanje za delo z orodji za komunikacijo. Na tej stopnji se učenci še vedno učijo osnov, ki jim bodo omogočile uspešno učenje vsebin na kasnejših stopnjah. Za učenje tujih jezikov je zelo uporabno orodje forum. $V$ tej fazi učitelj odpre forum s preprosto nalogo, lahko sam napiše prvi prispevek ali pa prepusti iniciativo učencem. Navodila naj bodo jasna in merljiva, npr. vsak učenec napiše vsaj en prispevek in komentar na prispevke drugih učencev v forumu, prispevek naj obsega dva do pet stavkov. Vsebina razprav $v$ forumu je drugotnega pomena, primarno je usvajanje dela $\mathrm{z}$ orodjem in socializacija $\mathrm{v}$ SUO. Na ta način se postopoma gradi skupnost in občutek sprejetosti, ki je nujen predpogoj za uspešno učenje v naslednjih fazah. $\mathrm{V}$ primeru, ko v SUO sodelujejo učenci iz različnih kulturnih in jezikovnih okolij, je ta faza namenjena tudi razvijanju občutka za drugačnost in razumevanje drugih kultur. Druga stopnja je zaključena, ko se udeleženci aktivno vključijo v razprave in prispevajo svoja mnenja ter reagirajo na prispevke drugih.

Tretja stopnja vključuje po obsegu manjše naloge, kot je npr. izmenjava, izbor in vrednotenje informacij ter krajše individualne ali sodelovalne naloge. Namen tretje faze je navajanje na sodelovalno delo v SUO s ciljem doseči uspešno delovanje skupine. Ko znajo učenci uporabljati orodja, so že socializirani in motivirani za delo v skupini ter so usvojili principe izmenjevanja informacij, postopoma pridemo do stopnje samostojnega sodelovalnega učenja.

Dejavnosti na četrti stopnji postanejo zahtevnejše, saj vključujejo višje taksonomske ravni znanja, kot je npr. uporaba znanja v novih situacijah, analiza, sinteza in vrednotenje. Vloga učitelja na tej stopnji je usmerjanje učnega procesa iz ozadja, brez nepotrebnega vmešavanja. Učitelj občasno povzame dotedanje delo, predlaga nove teme ali vidike, če je potrebno ob primernem trenutku sodeluje pri dokončanju dejavnosti. Četrta stopnja je zaključena, ko učenci s sodelovalnim delom pridejo do dogovorjenega rezultata.

Učenci na vsaki stopnji postajajo samostojnejši in prevzemajo večjo odgovornost za lastno učenje in za uspešno učenje v skupini. Zadnja - peta stopnja je namenjena razvijanju samorefleksije in kritičnega pogleda na lastni proces učenja. $\mathrm{Za}$ pouk tujih jezikov so $\mathrm{v}$ ta namen razvita orodja kot so jezikovni listovnik ali portfolio.

\subsection{Načelo postopnosti pri uvajanju sodelovalnega spletno podprtega učenja}

Zgoraj opisani model upošteva načelo postopnosti, ki je po našem mnenju ključno za uspešno in učinkovito uvajanje spletno podprtega učenja tujih jezikov. Sodeč po opažanjih šolskega polja se spletno podprto poučevanje in učenje še ni uveljavilo v tako širokem krogu, kot bi se glede na dostopnost IKT lahko. Za izvajanje učnega procesa na spletu sicer veljajo podobne zakonitosti in didaktična načela kot za tradicionalni pouk, vendar pa je potrebno še dodatno znanje o načrtovanju učne poti v spletnem okolju. Pri uvajanju spletno podprtega učenja je zelo pomembno, da učitelj učne dejavnosti načrtuje postopno in da sproti preverja razumevanje snovi in doseganje ciljev. Učenje v SUO je proces, ki zajema tako učenje 
tehnik dela z orodji in tehnik komuniciranja kot tudi vsebinsko učenje. Tako kot pri uporabi katerekoli nove metode poučevanja velja torej tudi za učenje v SUO didaktično načelo postopnosti.

\section{SKLEPNE MISLI}

V Sloveniji smo v začetnem obdobju spletno podprtega učenja tujih jezikov. Mladi $\mathrm{v}$ prostem času pogosto in na različne načine uporabljajo IKT za zabavo in komuniciranje, pri pouku pa veliko manj. Menim, da bodo učitelji didaktično vrednost IKT sčasoma prepoznali ter sprejeli in usvojili metode spletno podprtega učenja, tako pri tujih jezikih kot tudi pri drugih predmetih. Ob zavedanju dejstva, da postaja dandanes vseživljenjsko učenje, razširjanje obzorij izven svojega primarnega poklica in v končni posledici tudi zamenjava poklica, nekaj običajnega, dobi uporaba IKT pri pouku novo dimenzijo.

\section{LITERATURA}

EMPIRICA (2006) Benchmarking Access and Use of ICT in European Schools 2006. Final Report from Head Teacher and Classroom Teacher Surveys in 27 European Countries. 25. avgust 2006. http://ec.europa.eu/information_society/eeurope/i2010/ docs/studies/final_report_3.pdf.

GERLIČ, Ivan (2010) Stanje in trendi uporabe informacijsko komunikacijske IKTe $\mathrm{v}$ slovenskem izobraževalnem sistemu. Vzgoja in izobraževanje $v$ informacijski družbi [Elektronski vir]: zbornik konference, 111-118.

KAČ, Liljana (2009) Razvijanje IKT-zmožnosti v novih učnih načrtih za nemščino oz. tuje jezike v osnovni šoli in gimnaziji. M. Orel, M. Vreča, A. Lenarčič, M. Kosta (ur.), Mednarodna konferenca Splet izobraževanja in raziskovanja z IKT SIRIKT 2009. Ljubljana: Arnes, 56.

KAČ, Liljana/KOŠIR, Metka (2011) S skrbno načrtovanim usposabljanjem do ekompetentnih učiteljev tujih jezikov. A. Bačnik, B. Trstenjak, K. Blagus, M. Kosta (ur.), Mednarodna konferenca Splet izobraževanja in raziskovanja z IKT SIRIKT 2011 (zbornik). Ljubljana: Arnes, 286-292.

KALIN, Jana (2004) Vloga medijev pri sodobnem pouku in presojanje njihove učinkovitosti. M. Blažič (ur.), Mediji v izobraževanju. Novo mesto: Visokošolsko središče, 210-215.

LAVRIČ, Miran idr. (2010) Mladina. Končno poročilo o rezultatih raziskave. MŠŠ. PEKLAJ, Cirila/ KALIN, Jana/PEČJAK, Sonja/PUKLEK LEVPUŠČEK, Melita, VALENČIC ZULJAN, Milena/AJDIŠEK, Neža (2009) Učiteljske kompetence in doseganje vzgojno-izobraževalnih ciljev v šoli. Ljubljana: Znanstvena založba Filozofske fakultete.

PODGORŠEK, Saša/ŠULIGOJ, Sonja (2011) Učna pot pri pouku tujih jezikov v spletnem učnem okolju, Schaurein, 23/1. 
REBOLJ, Vanda (2008) E-izobraževanje skozi očala pedagogike in didaktike. Radovljica: Didakta.

SALMON, Gilly (2004) E-tivities - Der Schlüssel zu aktivem Online-Lernen. Zürich: Orell Füssli Verlag.

SCHULMEISTER, Rolf (2006) eLearning: Einsichten und Aussichten. München: Oldenbourg Wissenschaftsverlag.

SETZINGER, Joyce (2010) Moodle: Vodnik po orodjih za učitelje. 11. junij 2011. http://www.cats-pyjamas.net/.

SULČIČ, Viktorija (2008) E-izobraževanje v visokem šolstvu. Koper: Fakulteta za management.

UČNI načrt. Nemščina [Elektronski vir]: gimnazija: splošna, klasična in strokovna gimnazija: obvezni predmet in matura (420 ur), izbirni predmet (140 ur). Predmetna komisija Nada Holc [et al.]. Ljubljana: MŠŠ, Zavod RS za šolstvo. 11. junij 2011. http://portal.mss.edus.si/msswww/programi2010/programi/ media/pdf/un_gimnazija/un_nemscina_gimn.pdf.

WARSCHAUER, Mark (1996) Computer Assisted Language Learning: an Introduction, Fotos S. (ur.), Multimedia language teaching. Tokyo: Logos International, 3-20.

\section{POVZETEK}

\section{Spletno podprto učenje in poučevanje nemščine na sekundarni ravni}

$\mathrm{V}$ prispevku so orisane različne oblike integracije IKT v pouk nemščine. Natančneje je predstavljena le ena oblika, to je spletno podprti pouk. Uspešnost integracije spletno podprtega pouka je odvisna od različnih dejavnikov. V prispevku smo se osredotočili na načelo postopnosti, ki ima ključni pomen $\mathrm{v}$ petstopenjskem modelu uvajanja spletno podprtega učenja. Model smo v prispevku predstavili in analizirali njegov pomen za spletno podprti pouk nemščine in posredno drugih tujih jezikov.

Ključne besede: spletno podprto učenje, e-učenje, kombinirano učenje, spletno učno okolje, didaktika tujih jezikov

\section{ABSTRACT}

\section{Web-based teaching and learning of the German language on the secondary level}

The paper outlines different forms of integration of technology in teaching German. Specifically it presents only one form, this is a web-based instruction. The success of the integration of web-based teaching depends on several factors. In this paper we focus on the principle of gradualism, which is of key importance in the five stage model introducing web-based learning. In this paper we present the model and analyze its relevance for web-based teaching German.

Keywords: web-based learning, e-learning, blended learning, online learning environment, foreign language teaching methodology 